Doubling Actors in Richard II', Paul Menzer (ed.), Inside Shakespeare: Essays on the Blackfriars Stage (Selinsgrove, PA, 2006), 149-55.

28 McMillin and MacLean, The Queen's Men, 107; Kathman, 'How Old?'

29 Ibid, 175.

30 A 'pastance' is, according to the Oxford English Dictionary, a 'recreation', likely etymologically derived from the Middle French 'passetemps' ('pastance', n.).

31 The Chester Assembly Book specifies that the fees are paid 'because yt shall not be alledged that this restraynte is for sparinge of the treasury of this Citie'; it is possible that these were payments not to play. See Baldwin, Clopper, and Mills, ReED: Cheshire, 1.202-3, 1.259.

32 Roberts-Smith, 'The Red Lion and the White Horse: Inns Used by Patronized Performers in Norwich, 1583-1624', Early Theatre 10.1 (2007), 110-20.

33 Walsh works forward from the Queen's Men's True Tragedy and Famous Victories of Henry the Fifth to Shakespeare's Richard III and Henry V in successive chapters of Shakespeare, the Queen's Men. See also Griffin's account of the refinement, secularization, and politicization of the genre of the history play since before the Reformation, in chapters 2 and 3 of Playing the Past, 22-46. I disagree with his characterization of The Famous Victories of Henry the Fifth as a London play (its audience was much more likely primarily a provincial one), but support his basic contention that sixteenth-century plays treated time and space in complex and sometimes internally inconsistent ways.

\title{
'The Great Choreographer': Embodying Space in Fuenteovejuna
}

Social dances embody and perform kinesthetic structures of courtesy and courtship. The relative positions of dancers, their gestures, eye contact and posture, and manipulation of personal accoutrements (hats, gloves, fans, etc.), communicate at once both social hierarchies and personal desire. Furthermore, floor patterns, large and small group forms, contact between male and female dancers, and varying musical rhythms all contribute to the degrees and modes of human interaction, whether legitimized or transgressive. This was no less true in early modern Europe as it is today as is evident in the various treatises on dance in Europe such as Raoul Feuillet's Chorégraphie, ou l'art de decrier la dance, Pablo Minguet e Irol's Arte de danzar a la francesa, and Juan de Esquivel Navarro's Discursos sobre el arte del danzado. Nevertheless, of all of the branches of performance historiography, historical dance 
reconstruction is possibly the stickiest and the least understood. If theatrical performance is by nature ephemeral, printed dramatic texts at least provide some evidence of performance content. Feuillet does not develop his system of dance notation until the eighteenth century, and even then he declares, 'It is almost useless to explain terms related to dance. ${ }^{11}$ In Spain, Esquivel's text uses narrative rather than notation to describe a range of individual steps and dances. ${ }^{2}$ Cotarelo y Mori calls these descriptions 'very obscure', ${ }^{3}$ however, and even Lynn Matluck Brooks admits that 'any attempt to decipher his meaning requires constant reference to related texts, as well as speculative and creative leaps'.4

Elsewhere, I have argued that the Spanish comedia appropriates and manipulates culturally embedded notions of space and movement to create dramatic meaning. ${ }^{5}$ These spatial organizations are, as in Bourdieu's notion of habitus, both structured and structuring. Bourdieu defines habitus as:

[the] system of durable, transposable dispositions, structured structures predisposed to function as structuring structures, that is, as principles which generate and organize practices and representations that can be objectively adapted to their outcomes without presupposing a conscious aiming at ends or an express mastery of the operations necessary in order to attain them. ${ }^{6}$

In this way, Bourdieu emphasizes the need to take into account, not only the structures of culture, but also the human capacity to manipulate those structures, whether consciously or unconsciously, for both individual and group expression. A wedding ceremony, for example, whether Catholic, Jewish, Same-Sex, Baptist, Indian, or Drive-Thru, is not according to Bourdieu, a simple variant, but 'a strategy which takes on its meaning within the space of possible strategies'7 That is, the habitus of the ceremony manipulates a variety of possible social structures and practices (e.g. a space, an authority, a gesture, a dress code, an exchange), and combines them strategically towards, in the words of Bourdieu, 'the maximizing of material and symbolic profit'. ${ }^{8}$ In an Orthodox Ashkenazi Jewish wedding ceremony, for example, the bride circles the groom seven times, physically embodying the symbolic notion that the bride's world now revolves around her husband's. Reform Judaism strategically rejects this tradition in order to articulate gender equality: both the bride and the groom circle each other. That is, a Reform Jewish wedding performs a habitus that is structured by one 'individual and collective practice', and strategically structures another.' 
The relationship between the current circumstances that motivate the practice, and the historical milieu in which that habitus developed, is realized, in Bourdieu's own words, through its performance. This relationship is analogous to Pavis's definition of mise-en-scène: the interrelationship of dramatic text and performance text. ${ }^{10}$

practices cannot be deduced either from the present conditions which may seem to have provoked them [performance text] or from the past conditions which have produced the habitus, the durable principle of their production [dramatic text]. They can therefore only be accounted for by relating the social conditions in which the habitus that generated them was constituted [dramatic text], to the social conditions in which it is implemented [performance text], that is, through the scientific work of performing [staging] the interrelationship of these two states of the social world that the habitus performs, while concealing it, in and through practice. ${ }^{11}$

It is not enough, however, simply to deduce individual structures through historical, objectivist means, nor to analyze them solely through subjectivist, phenomenological interpretation. As I will show in this essay, a habitus of the corral stage may be articulated through an analysis of a performance of this interrelationship. The analysis of the habitus of performance is both broader and deeper than that of theater semiotics in that it does not merely interpret signifier/signified relationships of dramatic and/or performance texts, but rather re-utters the structuring and organizing strategies of all aspects of dramatic work, past and present.

The structures of habitus function differently on the stage, however, than they do in the world, although they do so in a way analogous to the function of stage properties. A stage property functions on two levels: its meaning unto itself as an inanimate object, and its meaning in context, which the actor's use of that object alters or emphasizes. Playwrights and directors actively manipulate what Frances Teague calls the 'dislocated function' of a stage property towards a specific dramatic end. A box of matches is a matchbox, but 'if an actor wishes to call a matchbox a gun, he may do so'. ${ }^{12}$ Habitus, as we shall see, may be similarly 'dislocated' for dramatic purposes.

The Spanish comedia appropriates culturally-embedded notions of space and movement to create dramatic meaning. Lope's Fuenteovejuna structures dramatic space by dislocating the habitus of early modern dance. This essay will address the means by which dance and kinesthetic movement 
structure and communicate the 'dislocated habitus' of Lope's early modern corral stage. Although attempts to reconstruct a complete dance, or even an individual dance step, will never be completely accurate, Esquivel's treatise, Discursos sobre el arte del danzado, in conjunction with other supporting evidence, reveals culturally-laden structures of body carriage, body interactions, and treatments of space that can inform interpretations of Spain's classical theater.

As he makes clear, Esquivel's instruction is designed to distinguish the gentleman from the commoner:

So it is fitting that the greatest Monarchs and private citizens, who have the means to do it, practice it, as much for pleasure and entertainment, as for majesty and refinement, qualities which naturally proceed from the Dance, testifying to its nobility by their very manifestations. ${ }^{13}$

Esquivel then goes on to outline specific corporeal structures, most notably a still and upright body carriage, which dance historians have shown to be unique to Spain in Baroque European dance. ${ }^{14}$ Brooks notes that the stance and comportment of the Spanish gentleman ... would have permitted himself less freedom of torso action — strutting, swaggering, épaulement [than] ... his counterparts in other nearby lands'. ${ }^{15}$ Esquivel instructs:

In dance, the Body must be held erect, without artifice, with much non-chalance ... without bending over to look at your feet, or at anything else. This is because putting on airs and presumptuous behavior are things that tarnish all, however well one performs. ${ }^{16}$

Brooks also finds that international observers especially note the 'austerity of Spanish etiquette and movement in general, reflected in dancing style'. ${ }^{17}$ In the early eighteenth century, Italian poet and librettist Jacopo Martello commented that Spanish dance was 'withdrawn within itself, and even in light movements of the waist maintains a sense of decorous dignity inseparable from the gravity of the nation'. ${ }^{18}$

Spanish court dance and early modern Spanish swordplay share this upright body carriage in common. Don Luis Pacheco de Narváez's 1600 treatise Libro de las grandezas de la espada provides detailed guidelines for the standards of body carriage and physical appearance for maximum success in self-defense. ${ }^{19}$ Swordsmen 'must have, first and foremost, an upright 
head, lively watchful eyes, a deep voice, the chest held high' (my translation and emphasis). ${ }^{20}$ The upright head and high chest that Narváez emphasizes are a direct result of the principles of Euclidean geometry used to develop the Spanish combat style. Narváez concluded that the most effective thrust was accomplished with the sword at a right angle to the body as the radius drawn by such an angle has the farthest reach relative to the opponent's position [fig. 1]. ${ }^{21}$ Nevertheless, as Narváez also indicates, character, in addition to geometry, also makes the swordsman who must have, not only 'slender feet' and be 'of medium height', but he must also be 'composed in gait and temperament, and covetous of fortune and honor' (my translation and emphasis). ${ }^{22}$

Spanish dance and Spanish swordplay, then,

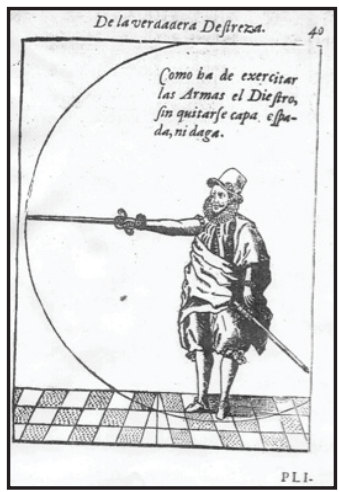

Fig. 1 Proper posture and sword position as shown in Libro de las grandezas de la espada (f. 40r). Coustesy of Universitat de València, Biblioteca Histórica. demonstrate a clear, intimate connection between physicality, culture, and class. Both the Discursos sobre el arte del danzado and the Libro de las grandezas de la espada are expressly addressed towards the noble gentleman. He must learn both arts: to dance with 'galán' (gallantry) and to fight with 'destreza' (skill) in order to establish himself as a worthy courtier. Lope appropriates this corporeal habitus in Fuenteovejuna, establishing a binary opposition between the noble, but tyrannical, Commander of Calatrava, and the abused peasants of the town. ${ }^{23}$ The very opening of the play, in fact, addresses the issue of nobility and courtesy when the Commander is offended by the late arrival of the Master of Calatrava.

COMENDADOR La obligación de la espada

que se ciñó el mismo día

que la cruz de Calatrava

le cubrió el pecho, bastaba

para aprender cortesía.

COMMANDER The day they pinned the sacred cross

Of our crusade on his young breast

He swore an oath compelling him

To treat all men with courtesy. 
The upright, open body posture of the Spanish gentleman provides a prominent display for the insignia of one of the prestigious Spanish military orders. Membership was restricted to the nobility with no convert ancestry, so the coveted insignia of the order splashed across the breast came to project an instant statement of stature and class. Velázquez himself struggled for years to document his qualifications; the cross of Santiago in this selfportrait was added to Las meninas more than two years after the painting's completion [Fig. 2].

Not only does the framing conflict of Fuenteovejuna highlight tensions between the Orders of Santiago (Isabel loyalists), and Calatrava (supporters of her rival Juana), but also Lope juxtaposes the physical presence and posture of the noble members of these orders with that of the down-to-earth farming population. Perhaps the most down-to-earth character, the gracioso Mengo, places these two social classes in the starkest corporeal contrast as he graphically describes the wounds he received from a beating after attempting to protect a townswoman from the Commander's advances:

MENGo Señores,

aquí todo el mundo calle.

Como ruedas de salmón me puso los atabales.

MENGo Not me!

If you want my advice, go home.

Keep your heads down and say nothing.

His men beat me so hard, my arse

Looks like a pair of raw salmon steaks.

In addition to body posture, Lope juxtaposes the stance and foot position of the nobles and peasants. Both Esquivel and Narváez emphasize the importance of a 'firm, stable' and balanced stance for excellence in dance as well as swordplay. ${ }^{25}$ The 'planta natural' as Esquivel calls it, forms the balanced starting position for all dance steps [Fig. 3].

The planta natural along with the reverencia, or bow, are so important, that they are the only positions or steps in the treatise with an accompanying illustration. Esquivel describes two different types of reverencia, the cierta and the galana, which both begin from the planta natural. The reverencia is perhaps the most common dance step because, as Esquivel explains, it begins and ends every court dance. Interestingly, the basic opening position for a Spanish style sword fight is the very same planta natural. [Fig. 4] For 


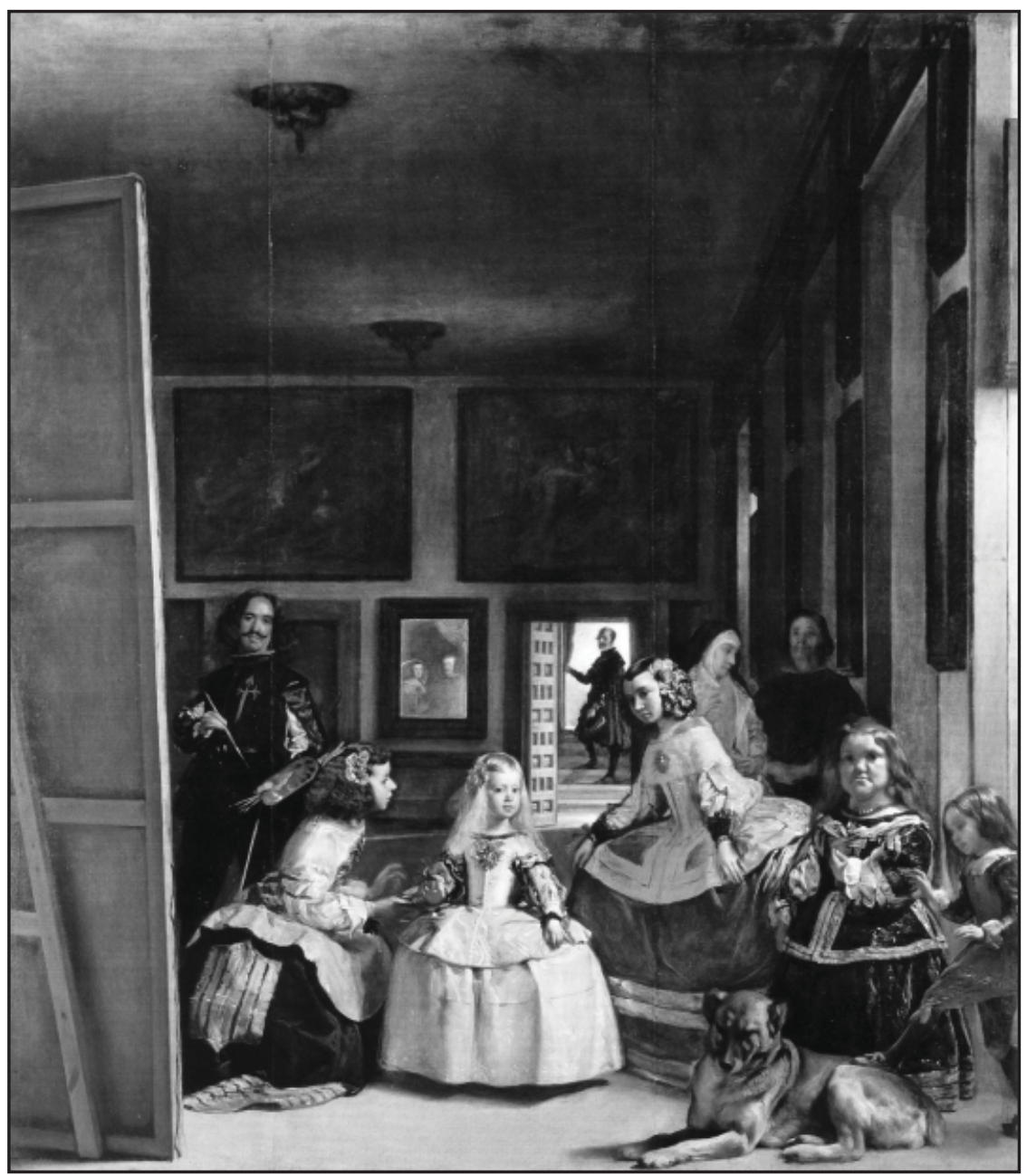

Fig. 2. Las Meninas o La familia de Felipe IV, Diego Rodríguez de Silva y Velázquez (1656), P1174. Courtesy of the Museo del Prado.

Narváez, a swordsman's foot position should be 'perfect, firm and durable', like a building's foundation. ${ }^{26}$ With the feet placed in an open stance, more or less at a right angle, this posture can be seen in any number of portraits of royals and nobles in Spain throughout the early modern period, including Velázquez's 1624 portrait of Philip IV in the Metropolitan Museum of Art [Fig. 5]. 


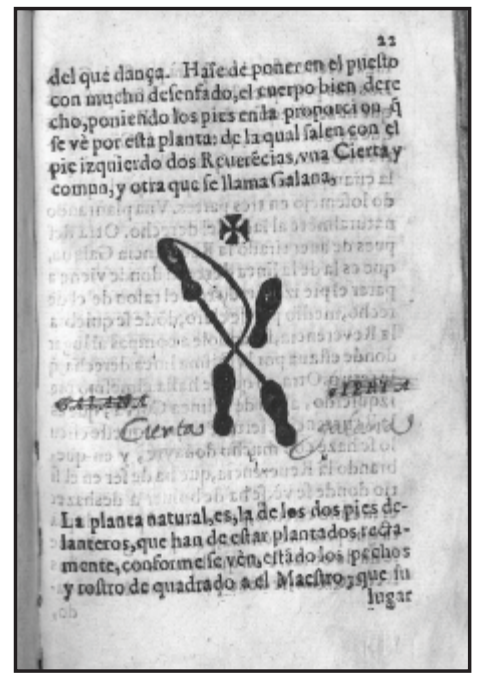

Fig. 3. Esquivel's planta natural and reverencias, (f. 22r), courtesy of the Hispanic Society of America, New York

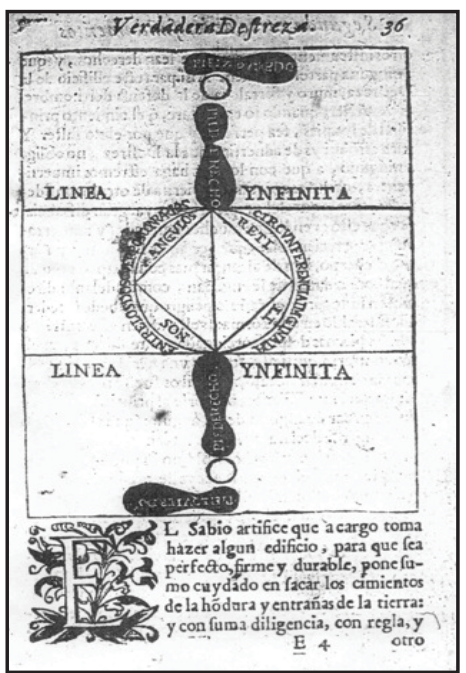

Fig. 4. Narváez's planta natural (f. 36r), courtesy of Universitat de València, Biblioteca Histórica.

Lope plays with this physical choreography in when Frondoso, a young peasant, metatheatrically greets his love interest, Laurencia, and her friend playing the role of a city gentleman:

FRONDOSO Dios os guarde, hermosas damas.

LAURENCIA ¿Damas, Frondoso, nos llamas?

FRONDOSO Andar al uso queremos.

FRONDOSO Cordial greetings, fair ladies.

LAURENCIA Ladies, Frondoso, why call us ladies?

FRONDOSO I'm following the city fashion.

This scene is already of special spatial interest as it represents Lope's break with the Aristotelian unities of action and place. However, the implied reverencia in Frondoso's greeting serves as a physical intertext of the scene immediately prior and belies the spatial transition from the castle of the Master of Calatrava to the well in the centre of town. Interestingly, Frondoso's 'city fashion' speech further addresses the importance of a well-placed foot for the upper class. Recall Narváez's description of the ideal physical qualities 


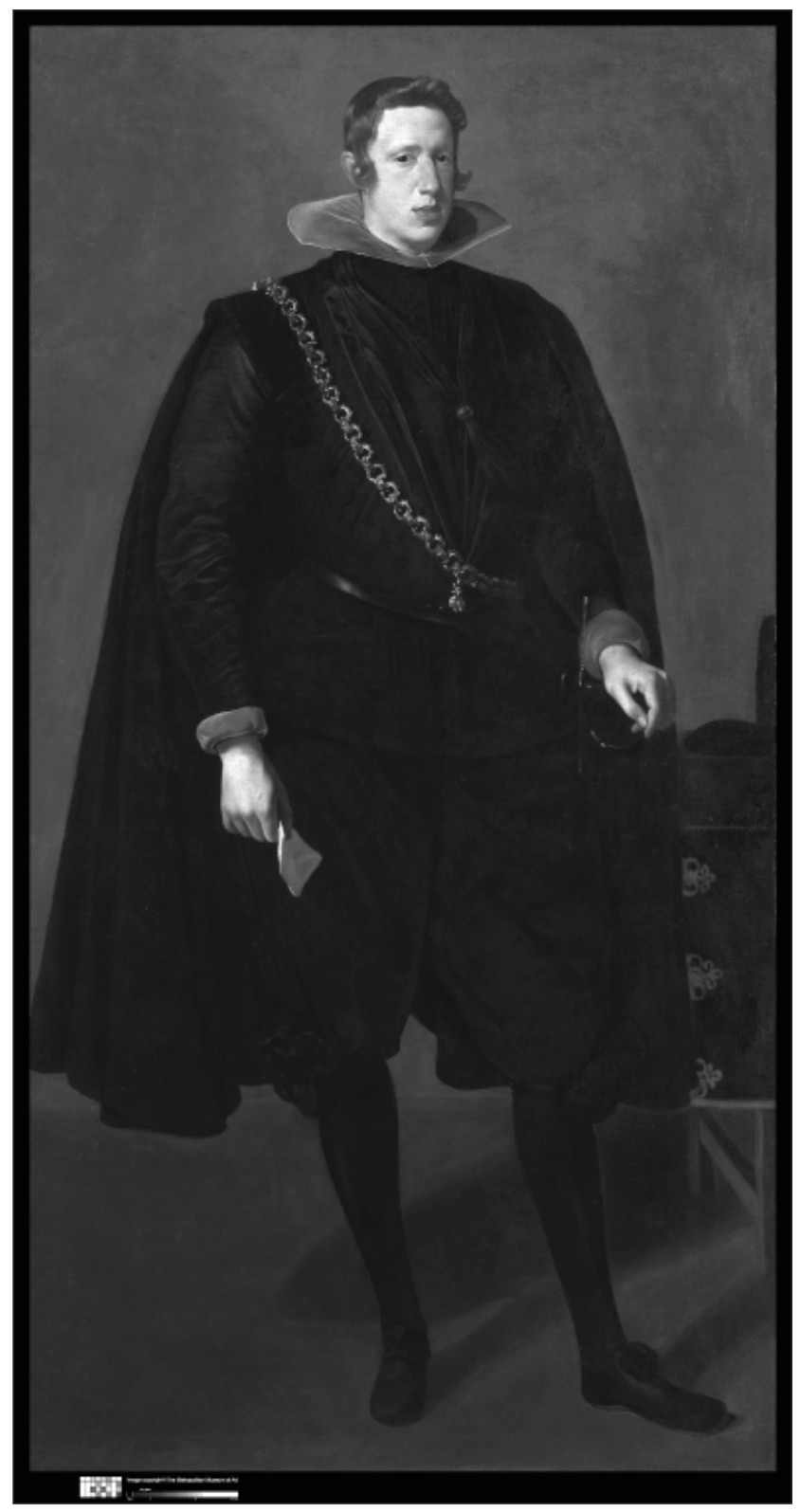

Fig. 5 Diego Velázquez, Philip IV (1624). Image by permission of the Metropolitan Museum of Art. Image source: Art Resource, NY. 
for a successful swordsman which included slender feet ('los pies enxutos'). ${ }^{27}$ As Frondoso enumerates the ways in which the city is 'upside down', he jokes:

FRONDOSO Andar al uso queremos ...

Gravedad, al descontento;

a la calva, autoridad;

donaire, a la necedad;

$\mathrm{y}$ al pie grande, buen cimiento.

FRONDOSO I'm following city fashion.

Everything's upside down ...

Their cynicism is gritty,

Their bald heads are distinguished and

Their big feet are firm foundations.

That is, the 'city fashion' is to sugarcoat undesirable physical qualities in positive terms. In this case, big feet become Narváez's stable building 'foundations'.

One of the most emphatic lessons of courtly dance that Esquivel implores his reader to learn is that improper body carriage - especially excessive movement of the upper body and arms - pushes the boundaries of licit behavior. In fact, throughout the entire text of Esquivel's treatise, there is no description or reference to any arm movement whatsoever. Nor do the dances or dance schools he mentions address the dancing of (or with) women. The degrees of moral transgression of every social dance of the day were hotly contested, and only certain dances (those which Esquivel describes) were performed at court. The Inquisition constantly pressured public theaters to censor material, and yet the corral remained one of the only legitimized public spaces where popular non-courtly dances such as the zarabanda and the chacona could be performed. Although Fuenteovejuna is only one of hundreds of Spanish Golden Age plays that weave popular dance into the body of the performance, the dancing at Laurencia's and Frondoso's wedding at the end of act 2 is especially well-positioned. Lope brings the story to the height of tension and suspense when, at the very end of act 2 , the evil Commander interrupts the joyous celebration, arrests the groom, and steals the bride away for his own pleasure.

The habitus of licit and illicit movement, the permitted and the proscribed, is woven throughout the play as the social division of space is repeatedly compromised. Women's bodies, and men's homes and land are violated by the Commander's abuse of power. When no action is taken after her capture 
and escape from the Commander's clutches, Laurencia, a woman, crosses into the private space of the men's town meeting to incite them to retaliate. The women themselves, alongside the men, invade the noble Commander's castle to carry out the collective murder of the tyrant. The investigating inquisitors torture the bodies of the weakest townspeople. And, finally, the working-class townspeople are granted audience with Isabel and Ferdinand themselves; a highly transgressive meeting-of-the-minds between the highest and the lowest-born finally results in the condemnation of tyranny, the pardoning of the townspeople and the restoration of order in Castile.

Fascinatingly, Lope's dislocation of the habitus of Spanish dance is not limited to that of individual postures, steps, or even sequences of steps, but rather encompasses the variability of improvisation that develops in the form in Spain. Esquivel, in spite of his careful, detailed description of the steps and combinations of steps that make up specific dances, does qualify his strict adherence to traditional choreography by clarifying that 'If perhaps some adept wishes to adjust [these steps] to some other dance, he can do so, because for him who dances well, any sort of novelty shines, even though it might seem unsuitable. ${ }^{28}$ Although the musical idea of theme and variation is well known today, its first appearance in printed music does not occur until 1538 when the famous Spanish vihuelist, Luis de Narváez (no relation) published six variations, or 'diferencias' on the theme of 'o gloriosa domina' in volume four of Los seys libros del delfin. ${ }^{29}$ The Diccionario de la Real Academia Española, of 1726 incorporates dance into its definition of the word diferencia:

In pieces of instrumental music this is the name given to the different ways of playing one and the same piece. Also, in dances of the Spanish school, it is the name given to the variety of movements which are applied at different times to one and the same piece[.] ${ }^{30}$

Maurice Esses notes that the term mudanza was also used to designate 'any unified sequence of dance steps' both in the late-sixteenth century and later in the Diccionario de la lengua castellana of $1734 .{ }^{31}$ Covarrubias uses the term diferencia as a synonym for mudanza, which 'sometimes means, in dances, variations on them (diferencias dellos)'. ${ }^{32}$ Interestingly, the word diferencia also means a disagreement, or difference of opinion, a usage which is emphasized through its repetition in each of the first two scenes of Fuenteovejuna. The Commander presents himself as a resolver of conflicts as he reminds the 
young Master of Calatrava that he interceded on his behalf with the pope regarding his succession to the post:

COMENDADOR Debéisme honrar;

que he puesto por vos la vida

entre diferencias tantas,

hasta suplir vuestra edad

el pontífice.

COMMANDER You honour me

As you should, how often have I

Risked my life on your behalf

In these dangerous times?

And who intervened with His Holiness

When the question of your youth

Put your succession in doubt.

Here, Lope engages the multiple layers of meaning in the word which, as Boswell's translation illustrates, requires an extended text in English. The word is again introduced in act 1 , scene 2 when Frondoso's 'ladies' are asked to resolve a dispute:

FRONDOSO En aquesta diferencia

andas, Barrildo, importune.

FRONDOSO Barrildo, it's a discussion.

Please, keep a sense of proportion.

Here the word diferencia performs the multiple sides of the question at issue: whether or not love exists. That is, the introduction and the repetition of the idea of diferencias in each of the first two scenes of Fuenteovejuna plays with the double meaning of the word and plants for the spectator the notion of improvisational use of space that Lope develops throughout the play. The dislocation of the habitus of dance in Fuenteovejuna, then, appropriates and organizes cultural structures of kinesthetic movement, highlighting characterization, theme, and conflict. Perhaps Lope's focus on the body caused modern director Laurence Boswell of the Royal Shakespeare Company to call Lope de Vega 'The Great Choreographer. ${ }^{33}$

Laura L. VidLer 


\section{Notes}

1 'Il est Presque inutile d'expliquer les termes afectez a la Danse', in Raoul Auger Feuillet, Chorégraphie, ou l'art de décrire la dance, par caractéres, figures et signes demonstratifs (Paris, 1700), 1.

2 Juan de Esquivel Navarro, Discursos sobre el arte del danzado (Sevilla, Juan Gómez de Blas, 1642).

3 'muy obscuro' in Emilio Cotarelo y Mori, Colección de entremeses, loas, bailes, jácaras y mojigangas desde fines del siglo XVI á mediados del XVIII (Madrid, 1911), 237.

4 Lynn Matluck Brooks, The Art of Dancing in Seventeenth-Century Spain (Lewisburg, PA, 2003), 82.

5 Laura Vidler, 'Towards a Model of Historical Staging Reconstruction of Spanish Golden Age Theater: Fabia in Lope de Vega's El caballero de Olmedo'. The Theater of Teaching and the Lessons of Theater (Lexington, VA, 2005), 63-78.

6 Pierre Bourdieu, The Logic of Practice. Translated by Richard Nice (Palo Alto, 1990), 53.

7 Ibid, 16.

8 Ibid.

9 Ibid, 54.

10 Patrice Pavis, Languages of the Stage: Essays in the Semiology of the Theater, (New York, 1982), 135.

11 Bourdieu, 56 (my emphasis).

12 Frances Teague, Shakespeare's Speaking Properties (Lewisberg, PA, 1991), 17.

13 ' $\mathrm{Y}$ así es digno de que los grandes Monarcas y personas particulares, que tienen comodidad para ello, lo ejerzan, tanto por lo gustoso y entretenido, como por lo majestuoso y galante: efectos que naturalmente proceden de la Danza, y testifican su nobleza con lo que ellos de si propio manifiestan' (f. 5v). Translation in Lynn Matluck Brooks, The Art of Dancing in Seventeenth-Century Spain (Lewisberg, PA, 2003), 268.

14 Ibid, 83.

15 Ibid, 90.

16 'Ha de ir el Cuerpo danzando bien derecho sin artificio, con mucho descuido ... ni doblarle por mirarse a los pies, ni por otro accidente. Porque la afectación y presunción es cosa con que se desluce todo cuanto se obra bien' (f. 21-21v). Ibid, 283.

17 Ibid, 90.

18 Ibid, 90.

19 Luis Pacheco de Narváez, Libro de las grandezas de la espada (Seville, 1600). 
20 Ibid, f. 6v. 'Han de tener primeramente, la cabeza derecha, los ojos vivos, despiertos, la voz gruessa, el pecho alto'.

21 Ibid, f. 40r.

22 Ibid, f. 6v. 'los pies enxutos, en estatura mediano, en el andar compuesto, de provincia templada, codiciosos de honra y hazienda'.

23 For those unfamiliar with the play, a plot summary follows: Following the death of her brother, King Enrique IV de Trastámara, Isabel of Castile fights a war of succession against her niece, Juana, wife of the king of Portugal. The young master of the military order of Calatrava is convinced by his Commander, Fernán Gómez, to ally himself with Isabel's niece and rival Juana. They attack and successfully capture the strategically-placed Ciudad Real in the name of Portugal. Meanwhile, the Commander abuses his power as feudal lord in the small rural town of Fuenteovejuna. The townspeople try as long as they can to remain loyal to their sovereign lord as he usurps land holdings and rapes most of the women of the town. Finally, the townspeople retaliate and murder the Commander, declaring loyalty to Ferdinand and Isabel. An investigation by torture reveals only that the murder was committed by 'Fuenteovejuna', forcing the king and queen either to execute or pardon the entire town. They pardon everyone and promise to dispatch a new feudal lord to the town. Meanwhile, Ciudad Real regains control for Isabel and Ferdinand. The Master of Calatrava begs the king's and queen's pardon and declares his loyalty to them. Order is restored.

24 All translations of Fuenteovejuna in Lope de Vega, Fuenteovejuna. Trans. Laurence Boswell. (London, 2009).

25 Narváez, f. 36.

26 Ibid. 'perfecto, firme y durable'.

27 Narváez, f. 6v.

28 Esquivel, f. 16av. 'si tal vez algún diestro las quiere acomodar en otra parte, puede: porque en el que Danza bien, luce cualquier novedad, aunque parezca impropia'.

29 Luis de Narváez. Los seys libros del Delfín de música de cifras para tañer Vihuela. (Valladolid, 1538).

30 'En los tañidos de los instrumentos músicos se llaman así los diversos modos de tocar un mismo tañido: como también en la danza de la escuela española, la diversidad de movimientos, con que varias veces se llama un mismo tañido', in Real Academia Española, Diccionario de la lengua castellana, 6 vols (Madrid, 1726), 3.274-5.

31 Maurice Esses, Dance and Instrumental Diferencias in Spain During the 17th and Early 18th Centuries, 3 vols (Stuyvesant, NY, 1992), 1.6. 
32 'Algunas veces sinifica, en los bailes, las diferencias dellos', in Sebastián de Covarrubias Horozco, Tesoro de la lengua castellana o española, eds Ignacio Arrellano and Rafael Zafra, (Madrid, 2006), 1300.

33 Laurence Boswell interviewed by Isaac Benabu, Association for Hispanic Classical Theater Visual Studies Series, VSS101 (АнСт, March 5, 2010). DVD. http://www .comedias.org/AHCT/AHCT/Video_Catalogue.html 